\title{
DIRECT EFFECT OF WTO RULINGS: THE CASE FOR CONDITIONAL RECOGNITION
}

\author{
Xiuyan Fei*
}

\begin{abstract}
The issue of direct effect of WTO rulings is sovereignty-sensitive. It is also concerned with the concepts of supremacy, constitutionalism, the rule of law, checks and balances, and democracy. Although WTO rulings are binding on the parties to the disputes and establish the secondary obligations in the sense of international law, whether a WTO Member attributes direct effect to WTO rulings is a matter of national law. Most WTO Members deny direct effect of WTO rulings. That is the case in the EU and the US. Analysis of the EU and the US jurisprudence demonstrates that such denial has negative effects at both international and national levels. Considering the intent of WTO founders and WTO adjudicators, the institutional structure of the WTO, and its democratic deficit, it is justified to deny the direct effect of WTO rulings. From the perspectives of protecting individuals' interests, promoting international rule of law, and addressing denial's negative effects, WTO Members should grant conditional direct effect to WTO rulings. The benefits of such conditional direct effect are likely to outweigh the negative effects of the general denial.
\end{abstract}

INTRODUCTION

I. An ACADEMIC DEBATE CONCERNING LEGAL EFFECTS OF WTO Rulings

II. THE EU AND THE US JURISPRUDENCE ON THE DENIAL OF DIRECT EFFECT

OF WTO RULINGS ..................................................................4. 496

III. NEGATIVE EFFECTS OF THE DENIAL .................................................4 498

A. Negative Effects at the International Level .............................4498

B. Negative Effects at the National Level.................................501

IV. JustifiCATION OF DENIAL OF DiRECT EFFECT OF WTO Rulings ........503

A. Justification: From the Perspective of the Intent ................... 503

B. Justification: From the Perspective of Institutional Structure .505

C. Justification: From the Perspective of Democratic Legitimacy506 V. Proposal: CONDITIONAL DiRECT EFFECT OF WTO RULINGS ................509

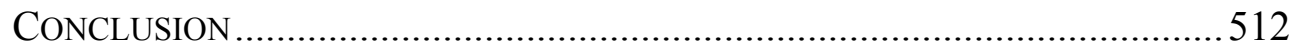

\section{INTRODUCTION}

The legal status of the rulings of the World Trade Organization

\footnotetext{
${ }^{*}$ Xiuyan Fei, Postdoctoral Fellow at the Institute of BRICS Legal Studies of the East China University of Political Science and Law. Research fields: International economic law. The author would like to thank the China Law Society for its support (Project No. CLS (2015) ZDWT12).
} 
(WTO $)^{1}$ in national courts directly denotes the jurisdictional interactions between WTO tribunals and national courts, and further connotes the relationship between WTO law ${ }^{2}$ and national law, which is embedded in the relationship between international law and national law. Dualism and monism are two approaches which address the relationship between international law and national law. ${ }^{3}$ However, neither dualism nor monism explains the relationship between international law and national law adequately or satisfactorily. ${ }^{4}$ Since the second half of $20^{\text {th }}$ century, international law does not purely regulate the relations between States, but rather it penetrates into the domestic legal realm and may directly influence individuals' legal rights and obligations. Thus the function of international law is not distinctively separate from that of national law. ${ }^{5}$ It is well established that a State cannot justify its violation of international law by referring to national law. ${ }^{6}$ However, it is not settled to what extent international law has effect and whether it is directly applicable in the national legal regime, let alone the issue of direct effect of WTO law. The Marrakesh Agreement requires Members to ensure conformity of their laws, regulations and administrative procedures with their obligations under WTO law. ${ }^{7}$ However, WTO law does not specify its legal status in national law, or the legal status of WTO rulings in national courts.

\footnotetext{
${ }^{1}$ In this article, the phrase "WTO rulings" refers to the recommendations and decisions made by WTO panels (to the extent that they are not appealed) and those made by the Appellate Body, which are adopted by the WTO Dispute Settlement Body.

${ }^{2}$ The phrase "WTO law" is used to refer to the entirety of the WTO agreements, including the Marrakesh Agreement Establishing the World Trade Organization (Marrakesh Agreement), its four annexes, Members' schedules of commitments, and the commitments included in WTO accession protocols.

${ }^{3}$ Dualism stresses the doctrinal distinction between international law and national law. International law is perceived to deal with the relations between States, while, national law is perceived to regulate the relations of the States' citizens among each other and the relations of the citizens with their States. International law and national law exist separately and cannot replace or overrule each other. In case of a conflict between international law and national law, it is the national court that determines which law applies, given the dualist's presumption of the supremacy of the State. Monism assumes that international law and national law form one single legal order and international law can be applied directly within the national legal order. See JAMES CRAWFORD, SC AND FBA, BROWNLIE's PRINCIPLES of Public International LaW 48-49 (6d ed., Oxford 2012); Malcolm N. Shaw, International LAW 131-132 (6d ed., Cambridge 2008).

${ }^{4}$ Armin Von Bogdandy, Pluralism, Direct Effect, and the Ultimate Say: On the Relationship between International and Domestic Constitutional Law, 6 INT'L. J. ConSTIT. L. 397, 400 (2008).

${ }^{5}$ Yuval Shany, Regulating Jurisdictional Relations BetweEn NATiONAL AND INTERNATIONAL COURTS 12 (Oxford University Press 2007).

${ }^{6}$ See Shaw, supra n. 3.

${ }^{7}$ Article 16.4 of the Marrakesh Agreement provides "Each Member shall ensure the conformity of its laws, regulations and administrative procedures with its obligations as provided in the annexed Agreements."
} 
The WTO rulings become binding on the parties to the dispute after their adoption by the WTO Dispute Settlement Body (DSB). ${ }^{8}$ According to Article 21.1 of the Understanding on Rules and Procedures Governing the Settlement of Disputes (DSU), "prompt compliance with WTO rulings is essential to ensure effective resolution of disputes to the benefit of all Members." 9 In practice, implementation of WTO rulings is usually considered as a matter within a Member's political discretion, rather than a matter of judicial enforcement of the rule of international law. ${ }^{10}$ This article makes an original contribution by examining and analyzing national courts' denial of granting direct effect ${ }^{11}$ to WTO rulings, and proposing recognition of their conditional direct effect.

Direct effect is a sovereignty-sensitive issue, because it implies supremacy ${ }^{12}$ and is concerned with constitutionalism, the rule of law, separation of powers and checks and balances, and democracy. ${ }^{13}$ Most WTO Members have denied direct effect of WTO rulings, and the EU and the US are prime examples in this respect. Since the EU and the US have initiated the greatest number of WTO cases and thus gained the richest experience of handling WTO rulings, ${ }^{14}$ their national courts' approaches to WTO rulings are likely to be influential and instructive for other WTO Members. Thus the EU and the US are selected as examples in this article to expound national courts' jurisprudence in relation to the denial of direct effect of

\footnotetext{
${ }^{8}$ Peter Van den Bossche \& Werner Zdouc, The Law and Policy of the World Trade ORganization 310 (3d ed., Cambridge 2013).

${ }^{9}$ Art. 21.1 of the DSU.

${ }^{10}$ Ernst-Ulrich Petersman, Multi-Level Judicial Trade Governance without Justice? On the Role of Domestic Courts in the WTO Legal and Dispute Settlement System in Merit E. JANOW, THE WTO: Governance, Dispute Settlement And Developing Countries 964 (Victoria Donaldson \& Alan Yanovich eds, Juris Publishing, Inc. 2008).

${ }^{11}$ The term of "direct effect" derives from the EU law. In this article, "direct effect" refers to "the conferment upon private persons of obligations and rights whose protection can be claimed before national courts". Francesca Martines, Direct Effect of International Agreements of the European Union, 25(1) EUR. J. INT'L L. 129, 131 (2014). As to the nuanced different meanings of direct effect, see Alicia Hinarejos, On the Legal Effects of Framework Decisions and Decisions: Directly Applicable, Directly Effective, Self-executing, Supreme?, 14 EuROPEAN LAW JouRnal 620, 622-625 (2008).

${ }^{12}$ Marco Bronckers, From 'Direct Effect' to 'Muted Dialogue': Recent Developments in the European Courts' Case Law on the WTO and Beyond, 11 J. INT'L ECON. L. 885, 896 (2008).

${ }^{13}$ Thomas Cottier, A Theory of Direct Effect in Global Law, in THE Challenge OF WTO LAW: Collected Essays 322 (Thomas Cottier ed, Cameron May Ltd. 2007); Also see Bogdandy, supra 4; Robert Howse and Kalypso Nicolaidis, Legitimacy through "Higher Law"? Why Constitutionalizing the WTO Is a Step Too Far, in The Role of The Judge in International Trade Regulation: EXPERIENCE AND LESSONS FOR THE WTO 308 (Thomas Cottier and Petros C. Mavroidis eds, University of Michigan Press 2003).

${ }^{14}$ Bruce Wilson, Compliance by WTO Members with Adverse WTO Dispute Settlement Rulings: The Record to Date, 10 J. INT'L ECON. L. 397, 400 (2007).
} 
WTO rulings, which provide factual background for the offered analysis.

The structure of the paper is as follows. Part I describes an academic debate concerning legal effects of WTO rulings, contextualizing the issue of denial. Part II presents the relevant EU and the US jurisprudence, which is then taken as basis of discussion of the negative effects of the denial in Part III and the justifications for the denial in Part IV. Part V makes the case for the recognition of a conditional direct effect for WTO rulings. At last, the paper provides a conclusion.

\section{An ACADEmic Debate Concerning Legal EFFECts of WTO RulingS}

Bello and Jackson are two prominent and representative voices in the debate on the legal effects of WTO rulings. Bello used to consider that WTO rulings were not binding in the sense of traditional international law, because under the WTO dispute settlement mechanism, the WTO did not have a jailhouse or policemen, and there was no prospect of incarceration, injunctive relief, damages for harm inflicted or police enforcement. ${ }^{15}$ She claimed that the WTO was dependent on the Members' voluntary compliance, and the flexibility underlying voluntary compliance enables the WTO to accommodate the national exercise of sovereignty. ${ }^{16}$ Jackson, on the contrary, insisted that WTO rulings were binding in the sense of traditional international law. ${ }^{17} \mathrm{He}$ considered that WTO rulings established international law obligations on the losing party, which is required to change its measures in order to comply with WTO rulings. ${ }^{18}$ In addition, Jackson argued that the losing party did not have much flexibility in choosing the forms of implementation, because "compensation" or "retaliation" is only a fallback in the event of non-compliance. ${ }^{19}$

Bello's arguments are not compelling. According to Article 22.1 of the DSU, full implementation of WTO rulings to bring a measure into conformity with WTO law is preferred, where as compensation and retaliation are only temporary measures. ${ }^{20}$ Bello considered that due to the lack of central enforcement agencies, the WTO obligations were not binding but rather dependent on the Members' voluntary compliance. It should be

\footnotetext{
${ }^{15}$ Judith Hippler Bello, The WTO Dispute Settlement Understanding: Less Is More, 90(3) AM. J. INT'L L. 416-417 (1996).

${ }^{16}$ Ibid.

${ }^{17}$ John H Jackson, The WTO Dispute Settlement Understanding-Misunderstandings on the Nature of Legal Obligation, 91(1) AM. J. INT’L L. 60, 63 (1997).

${ }^{18}$ Ibid at 60.

${ }^{19}$ Ibid at 61 .

${ }^{20}$ Article 22.1 of the DSU: Prompt compliance with recommendations or rulings of the DSB is essential in order to ensure effective resolution of disputes to the benefit of all Members.
} 
noted that lacking central enforcement agencies is the common characteristic of international law, and it is not a reason to deny the binding nature of international law, but rather as the reason why the enforcement of international law relies heavily on the actions of national agencies. ${ }^{21}$ WTO rulings differ from national rulings in several aspects, relating to their binding degree, precedential effects, judicial implications, and the forms of enforcement. However, those differences do not prove that WTO rulings are not binding. It rather reminds us that different attitudes towards and different approaches to WTO rulings and national rulings are reasonable and understandable.

WTO rulings, compared with primary obligations to comply with WTO law, entail secondary obligations that the parties to the dispute should honor. ${ }^{22}$ The designation of the implementation of WTO rulings as secondary does not imply that the obligation to comply with WTO rulings is less important than that to comply with WTO law. This designation is merely a helpful way of expressing a distinction between the contents of WTO law and the results of a breach of WTO law. ${ }^{23}$ Without appropriate performance of secondary obligations, primary obligations will not be met as well. However, attention should be paid to different contexts of WTO rulings and WTO law. WTO rulings, which arise from the Members' disputes, are delivered by the panels and the Appellate Body (AB) in the light of WTO law, and are only binding on the parties to the dispute. ${ }^{24}$ In contrast, the WTO is an incomplete contract among sovereign States. ${ }^{25}$ It is a complex set of rules dealing with a broad spectrum of issues, such as tariffs, quotas, or food safety. ${ }^{26}$ The major part of WTO law, as it is now, originates from the Uruguay Round negotiations. Amendments to and authoritative interpretations of WTO law can be made pursuant to strict rules laid down in the Marrakesh Agreement. ${ }^{27}$ In this framework, each Member bears the obligation to keep its laws and policies in conformity

\footnotetext{
${ }^{21}$ See Eyal Benvenisti, Judicial Misgivings Regarding the Application of International Law: An Analysis of Attitudes of National Courts, 4 EuR. J. INT'L L. 159-161 (1993).

${ }^{22}$ Ernst-Ulrich Petersman, Implementation of WTO Rulings: The Role of Courts and Legislatures in the US and Other Jurisdictions (EC, China) para. 4 (Columbia University Conference on the WTO at 10, New York, April 6-7, 2006).

${ }^{23}$ See Alan E Boyle, State Responsibility and International Liability for Injurious Consequences of Acts Not Prohibited by International Law: A Necessary Distinction?, 39 INT'L \& CoMP. L. Q. 1, 10 (1990).

${ }^{24}$ See supra n. 8.

${ }^{25}$ Mitsuo Matsushita, Thomas J. Schoenbaum and Petros C. Mavroidis, The World Trade Organization: LaW, Practice, AND POlicy 23 (Oxford University Press 2006).

${ }^{26}$ See supra n. 8.

${ }^{27}$ Arts. IX and X of the Marrakesh Agreement.
} 
with WTO law. ${ }^{28}$ Therefore, although both WTO rulings and WTO law are binding, their legal effects may have different implications given their different origins, formations, and the scopes of applicability.

WTO rulings are binding on the parties to a dispute and create legitimate expectations among WTO Members. ${ }^{29}$ The question whether WTO rulings are of direct effect remains unresolved. The following section presents the relevant EU and US jurisprudence denying the direct effect of WTO rulings.

\section{The EU AND the US JuRISPRUDENCE ON THE DeNIAL OF Direct EFFECT OF WTO RULINGS}

Both the EU and the US courts deny direct effect of WTO rulings. In effect, individuals cannot directly base their claims on the WTO rulings. Instead, they frame their claims on the basis of relevant provisions of national law. For example, in the EU two firms complained that the European Commission's application of zeroing method was in breach of Article 2 of the basic anti-dumping regulation on the basis of the WTO ruling's condemnation of zeroing method in WTO case EC-Bed Linen. ${ }^{30}$ In the US, the plaintiffs in Timken argued that the Department of Commerce's (DOC's) application of zeroing method violated the US international obligations, because the DOC's zeroing method was similar to the EU's zeroing method challenged in EC-Bed Linen and found inconsistent with the Anti-Dumping Agreement by the AB. ${ }^{31}$ Therefore, the denial of direct effect of WTO rulings cannot prevent private parties from bringing cases with regard to the direct effect of WTO rulings to national courts, and national courts cannot circumvent the issue of direct effect of WTO rulings. They have to address it.

The common approach employed by the EU and the US courts in denying direct effect of WTO rulings is to distinguish the facts before them from those before the WTO tribunals. In Ritek and Prodisc the General Court of the EU (GC) considered that the AB's reasoning relating to zeroing was developed in connection with the first symmetrical method, which was a comparison of a weighted average normal value with a weighted average of prices of all comparable export transactions. ${ }^{32}$ The zeroing method used by the

\footnotetext{
${ }^{28}$ Art. XVI: 4 of the Marrakesh Agreement.

${ }^{29}$ See supra n. 8.

${ }^{30}$ See Case T-274/02 Ritek and Prodisc Technology v Council General Court [2006] ECR II-4305, para. 90.

${ }^{31}$ Timken Co. v. United States, CIT, 26 C.I.T. 1072 (CIT, 2002) 1242-1243.

${ }^{32}$ Supra n. 30, para. 100.
} 
Commission was applied in the context of the asymmetrical method, which was not prohibited either by Article 2.4.2 of the Anti-Dumping Agreement or Article 2(11) of the EU basic anti-dumping regulation. ${ }^{33}$ Thus by distinguishing the facts, the GC did not consider how the WTO ruling in EC-Bed Linen would apply to this case. In the US, the US Court of International Trade (CIT) in Timken rejected the plaintiffs' allegation, inter alia on the basis that the zeroing method condemned by the WTO AB in EC-Bed Linen was the EU's method, not the one used in the US. ${ }^{34}$ Therefore, the WTO ruling in EC-Bed Linen had little impact on the US jurisprudence.

The differences exist also in the US and EU courts' nuanced attitudes towards and the grounds for the denial of direct effect of WTO rulings. The US courts were explicit in stating that WTO rulings were "not binding on the United States, much less this court". ${ }^{35}$ In contrast, the EU courts never explicitly stated that WTO rulings were not binding on them. There are two main reasons for the US courts' denial of direct effect of WTO rulings. First, Section 102 of the domestic Uruguay Round Agreements Act (URAA) explicitly provides that WTO rulings do not have binding effects under US law and individuals cannot challenge US law consistency with WTO law. Second, the US courts consider that the issue of implementation of WTO rulings is not their domain, but falls exclusively within the area of competence of the executive. ${ }^{36}$ The EU courts hold that the legal effects of WTO rulings are no more capable of conferring rights upon individuals than WTO law. Since WTO law does not have direct effect, neither do WTO rulings. ${ }^{37}$ To some extent, the EU courts attach the legal effect of WTO rulings to that of WTO law. The lack of reciprocity is another ground for the denial of direct effect of WTO rulings by the EU courts. The Court of Justice of the European Union (CJEU) pointed out that "the most important commercial partners" of the EU excluded WTO law from the rules that were used to review the legality of their domestic laws, and such lack of

\footnotetext{
${ }^{33}$ Ibid paras. 101-103.

${ }^{34}$ Supra n. 31.

${ }^{35}$ Corus Staal BV, Et Al. V. Dept. of Commerce, Et Al., Federal Circuit, 395 F.3d 1343, 1348 (2005).

${ }^{36}$ The Federal Circuit in Corus StaalBv V. U.S. stated that we "will not attempt to perform duties that fall within the exclusive province of the political branches, and we therefore refuse to overturn Commerce's zeroing practice based on any ruling by the WTO or other international body unless and until such ruling has been adopted pursuant to the specified statutory scheme." Corus Staal Bv V. U.S., 502 F.3d 1370, 1373 (2007).

${ }^{37}$ The CJEU in FIAAM \& Fedon stated "A recommendation or a ruling of the DSB finding that the substantive rules contained in the WTO agreements have not been complied with is, whatever the precise legal effect attaching to such a recommendation or ruling, no more capable than those rules of conferring upon individuals a right to rely thereon before the Community courts for the purpose of having the legality of the conduct of the Community institutions reviewed." Cases C 120/06 P and C 121/06 P, FIAMM and Others v. Council and Commission [2008] ECR I-06513, para. 129.
} 
reciprocity would risk introducing an anomaly in the application of WTO law if the EU recognized direct effect of WTO law. ${ }^{38} \mathrm{~A}$ sensible presumption was that the CJEU referred to the US as one of "the most important commercial partners". Noteworthy, the US courts never expressed similar concerns.

Regardless of the grounds on which direct effect of WTO rulings is denied, the result is that private parties face difficulties in getting compensation for their losses which arise from a Member's failure to implement WTO rulings. ${ }^{39}$ The following section provides a detailed analysis of the negative effects of the denial of direct effect of WTO rulings.

\section{NEGATIVE EFFECTS OF THE DENIAL}

The denial of the direct effect of WTO rulings implicates that what is illegal before the WTO tribunals may be legal before national courts. This not only blocks smooth cooperation between the WTO tribunals and national courts, but also damages international rule of law. This section expounds negative effects from international and national perspectives.

\section{A. Negative Effects at the International Level}

According to Article 3.7 of the DSU, the aim of the WTO dispute settlement is to secure a positive solution to a dispute. ${ }^{40}$ Neither any panel

\footnotetext{
${ }^{38}$ Case C-377/02, Van Parys [2005] ECR I-01465, para. 53.

${ }^{39}$ Schiemann called the plaintiffs of FIAMM and Fedon in FIAMM and Others v. Council and Commission "innocent victims". FIAMM and Fedon were the companies whose business activities had nothing to do with bananas, but they suffered from the US retaliation due to the EU's failure to implement the WTO ruling of EC-Bananas, which condemned the European Community regime governing the import of bananas. Schiemann stated that "the Union should be liable for doing something which had caused them substantial harm - notwithstanding the fact that neither of them had anything whatsoever to do with bananas - and they were the innocent victims of retaliatory measures taken by the United States." See Konrad Schiemann, The State's Liability in Damages for Administrative Action, 33(5) FordHAM InTERNATIONAL LAW JOURNAL 1548, 1552 (2011).

${ }^{40}$ Article 3.7 of the DSU: Before bringing a case, a Member shall exercise its judgment as to whether action under these procedures would be fruitful. The aim of the dispute settlement mechanism is to secure a positive solution to a dispute. A solution mutually acceptable to the parties to a dispute and consistent with the covered agreements is clearly to be preferred. In the absence of a mutually agreed solution, the first objective of the dispute settlement mechanism is usually to secure the withdrawal of the measures concerned if these are found to be inconsistent with the provisions of any of the covered agreements. The provision of compensation should be resorted to only if the immediate withdrawal of the measure is impracticable and as a temporary measure pending the withdrawal of the measure which is inconsistent with a covered agreement. The last resort which this Understanding provides to the Member invoking the dispute settlement procedures is the possibility of suspending the application of concessions or other obligations under the covered agreements on a discriminatory basis vis-à-vis the other Member, subject to authorization by the DSB of such measures.
} 
nor the $\mathrm{AB}$ has explained what kind of solution is qualified as a "positive" one. However, pursuant to the principle pactasuntservanda, under Article 26 of the Vienna Convention on the Law of Treaties (VCLT), it is inferred that good faith should be attached to a WTO Member's implementation of WTO rulings in consideration of a positive solution. Good faith is one of the fundamental principles of international law. ${ }^{41}$ It entails the elements of pactasuntservanda, honesty, fairness and reasonableness. ${ }^{42}$ It instructs a State to properly exercise inherent rights and obligations, and provides a limitation on a State's sovereignty. ${ }^{43}$ The touchstone of good faith is honesty, which is a subjective state of mind. ${ }^{44}$ Denial of direct effect of WTO rulings raises doubts about a Member's good faith in performance of WTO obligations.

First, it is against the principle of good faith for national courts to exclude the implementation of WTO rulings from their purview. The US courts consider that the implementation of WTO rulings is beyond their reach and WTO rulings are not binding on them. The EU courts, in order to leave room of maneuver for their legislative or executive bodies, also exclude direct effect of WTO rulings from their scope of adjudication. Considering the judiciary as a State's branch, it is fair to point out that national courts are not immune from the obligations to observe WTO law or implement WTO rulings. In the circumstances in which the US administrative authorities had committed to comply with WTO rulings, the US courts' statement that WTO rulings were not binding on them undermines the good faith of the administrative authorities' commitment. The AB has explicitly indicated that the decisions of a US court could not relieve the US of legal consequences of the discriminatory impact arising from the US court's decisions, and the US bears responsibility for the acts of all its organs, including the judiciary. ${ }^{45}$ The arbitrator in Brazil-Retreaded Tyres also held that the implementation through the judiciary could not be a priori excluded from the range of permissible actions that could be taken to implement WTO rulings. ${ }^{46}$ In addition, other WTO Members, such as the EU, emphasized that the implementation and

\footnotetext{
${ }^{41}$ Andrew D. Mitchell, Legal Principles in WTO DisPutes 110 (Cambridge University Press 2008); J. F. O'Connor, Good Faith In InTERnATIOnAl Law 119 (Dartmouth Pub. Co. 1991).

${ }^{42}$ Ibid, O'Connor 118.

${ }^{43}$ Steven Reinhold, Good Faith in International Law, 17. Available at http://papers.ssrn.com/sol3/papers.cfm?abstract_id=2269746 (last visited May 10, 2014).

${ }^{44}$ See supra n. 41.

${ }^{45}$ Appellate Body Report, US - Shrimp, WT/DS48/AB/R, para. 173. Also see Appellate Body Report, US-Zeroing (Japan), WT/DS322/AB/R, para. 182.

${ }^{46}$ Article 21.3 Arbitration Report, Brazil—Retreaded Tyres, WT/DS332/16, para. 68.
} 
enforcement of WTO obligations was also a responsibility of the judiciary which engaged in review of the actions of the State ${ }^{47}$ It is ironic that on the one hand, the EU upheld letting the judiciary bear the responsibility to implement WTO obligations, and on the other hand, the EU courts refused to review the EU legislative or executive measures in the light of WTO rulings. As for the US courts, holding that implementation of WTO rulings is not their responsibility is also against the principle of good faith in performance of State's obligations. Although US law provides that WTO rulings do not have binding effects under domestic law, it has been well recognized that national law cannot be used to justify a violation of international law. ${ }^{48}$ Hence, US law cannot justify the US courts' decisions that are inconsistent with WTO rulings.

Second, without analysis of different parameters of legal effects, it is not appropriate for national courts to equate the legal effects of WTO rulings with that of WTO law. The EU courts did not analyze whether the legal effects of WTO rulings differ from these of WTO law, but arbitrarily concluded that the legal effects of WTO rulings were not fundamentally different from that of WTO law. The obligation to implement WTO rulings, as a secondary obligation, is dependent on the primary obligation to comply with WTO law. However, it does not follow that the dimension of legal effects of WTO rulings is identical with that of WTO law. Attention should be paid to different parameters in understanding the nature of legal effects, which at least contains two facets in terms of broadness and intensity. From the perspective of broadness, WTO law is generally applicable to all the WTO members; while WTO rulings bind only the parties to a dispute. ${ }^{49}$ Therefore, the legal effects of WTO rulings are narrower than these of WTO law. However, from the perspective of intensity, for the parties to a dispute WTO rulings may be more penetrating than WTO law. WTO rulings are more specific and clear in addressing the WTO obligations and they contain suggestions on what steps the losing parties should undertake. Furthermore, in cases where a losing party commits to comply with WTO rulings, the effects of WTO rulings are intensified. Direct effect is more related with the legal parameters of intensity regarding the extent to which WTO rulings penetrate a Member's national legal system. Without conducting discreet analysis of the legal effects of WTO rulings, the EU courts are rather arbitrary in basing the denial of direct effect of WTO rulings on the jurisprudence concerning the denial of direct effect of WTO law. Moreover,

\footnotetext{
${ }^{47}$ Panel Report, EC-Trademarks and Geographical indications (US), WT/DS174/R/Add.2, para. 30.

${ }^{48}$ See Shaw, supra n. 3.

${ }^{49}$ See Appellate Body Report, Japan—Alcoholic Beverages II, WT/DS8/AB/R, at 13.
} 
the insufficient substantive analysis creates a situation in which the EU courts' denial of direct effect undermines the quality of their judgments, and thus frustrates the legitimacy of the EU courts. ${ }^{50}$

Third, the lack of reciprocity in recognizing direct effect of WTO rulings tends to result in a prisoner's dilemma. The EU courts were cautious to point out that their most important commercial partners did not recognize direct effect of WTO rulings, and the US courts indeed stated that WTO rulings were not binding on them, not to mention direct effect. One can infer that the US attitude towards WTO rulings fueled the EU courts' denial of direct effect of WTO rulings. Considering that the EU and the US are two of the most influential economies in the world and that the EU and the US approaches to WTO rulings might be instructive for other Members, the denial of direct effect of WTO rulings is more likely to prevail also among other WTO Members.

The denial of direct effect of WTO rulings raises doubts about a Member's good faith in implementation of WTO rulings, especially under the circumstances where a losing party has committed itself to comply with WTO ruling, but finally fails to honor that commitment. It encourages the disputants to resort to politics as the final manner of disputes' resolution, which may lead to endless negotiations and can damage international rule of law. In addition, the denial of direct effect also insulates sound dialogue between the WTO tribunals and national courts, aggravating the separation of WTO law and national law.

\section{B. Negative Effects at the National Level}

The denial of direct effect of WTO rulings cannot completely preclude the influence of WTO rulings at the national level. Private parties may refer to relevant WTO rulings to challenge the validity of national measures. Negative effects may prejudice private parties' interests and a Member State's judicial independence.

First, the denial of direct effect of WTO rulings may deprive private parties of the interests protected by the WTO rulings, in that the denial is likely to block the chain of legal effects of WTO rulings to reach the bottom of a Member State. Private parties do not directly participate in the WTO or WTO dispute settlement mechanism. Moreover, unlike human rights law,

\footnotetext{
${ }^{50}$ According to Weiler, the legitimacy of courts depends on the integrity of process and on both the substantive and communicative quality of the reasoning. See J. H. H. Weiler, The Rule of Lawyers and the Ethos of Diplomats: Reflections on the Internal and External Legitimacy of WTO Dispute Settlement, 35 J. W. T. 191, 204 (2001).
} 
WTO law is not designed to directly protect individuals against States' measures. ${ }^{51}$ However, according to the Preamble to the Marrakesh Agreement, the objectives of the WTO include increasing of standards of living and attainment of full employment for the sake of individuals. ${ }^{52}$ Private parties' interests should be taken into account when dealing with WTO issues. Due to the denial of direct effect, the security and predictability provided by WTO rulings for the multilateral trading system is also undermined, which may increase private business operators' transaction costs. ${ }^{53}$ Moreover, the denial indicates that no judicial remedies are available for those individuals, including private business operators and consumers, to recover damages arising from the Members' trade battle at the WTO. Therefore, the denial of direct effect may frustrate private parties' efforts to rely on WTO rulings to defend their interests.

Second, the denial of direct effect may undermine the principle of a Member's judicial independence. Both the EU and the US courts considered the implementation of WTO rulings not to be their task and they declined to review national measures in the light of the WTO rulings. It is understandable that according to the principle of separation of powers, each branch "must be confined to the exercise of its own function and not allowed to encroach upon the functions of the other branches". ${ }^{54}$ Thus national courts should not engage in implementation of WTO rulings since the implementation is usually considered a matter falling within the notion of foreign relations. However, national courts have to adjudicate the disputes concerning the validity of national measures which are brought indirectly on the basis of the WTO rulings. Thus national courts may find themselves in an awkward position. On one hand, national courts do not have the authority to review their legislative or executive organs' actions concerning the implementation of WTO rulings; While on the other hand, they have to deal with WTO-rulings-related claims. Such a dilemma challenges the judicial independence of national courts.

\footnotetext{
${ }^{51}$ See Hélène Ruiz Fabri, Is There a Case —Legally and Politically-for Direct Effect of WTO Obligations?, 25 EUR. J. INT'L L. 151, 173 (2014).

${ }^{52}$ The Preamble to the Marrakesh Agreement: Recognizing that their relations in the field of trade and economic endeavor should be conducted with a view to raising standards of living, ensuring full employment and a large and steadily growing volume of real income and effective demand, and expanding the production of and trade in goods and services, while allowing for the optimal use of the world's resources in accordance with the objective of sustainable development, seeking both to protect and preserve the environment and to enhance the means for doing so in a manner consistent with their respective needs and concerns at different levels of economic development.

${ }^{53}$ Edwini Kessie, Enhancing Security and Predictability for Private Business Operators under the Dispute Settlement System of the WTO, 34 J. W. T. 1, 5 (2000).

${ }^{54}$ M. J. C. Vile, Constitutionalism AND the Separation OF Powers 14 (Indianapolis 1998).
} 
In conclusion, the denial of direct effect of WTO rulings may produce negative effects at both international and national levels, supporting the case for its recognition by national courts. However, there are considerations justifying the denial. These are addressed in the following section.

\section{JUSTIFICATION OF DENIAL OF DiRECT EFFECT OF WTO RULINGS}

The issue of direct effect of WTO rulings is concerned with the supremacy of WTO rulings. It goes to the heart of fundamental constitutional questions both at the WTO and domestic levels. ${ }^{55}$ The AB is not a constitutional court, although it has a constitutional dimension due to its de facto power of interpreting WTO law. ${ }^{56}$ The Members did not intend to grant that much power to the WTO tribunals so as to enable the AB to fulfill a constitutional function. Similarly, the WTO adjudicators never made such a claim. Meanwhile, the WTO lacks the institutional structure and democratic legitimacy that would allow the $A B$ to function as a constitutional court. ${ }^{57}$ In effect, the AB's rulings should not be granted direct effect that penetrates national legal order. It may be then justified for national courts to deny direct effect of WTO rulings, apart from these situations in which a Member's legislature granted it. This section elaborates on the justifications of the denial of direct effect from the perspectives of the intent, the institutional structure, and democratic legitimacy of the WTO.

\section{A. Justification: From the Perspective of the Intent}

Neither the WTO Members nor the WTO adjudicators intended to grant direct effect to WTO rulings. This inference can be drawn from the Uruguay Round negotiations and the practice of WTO tribunals.

Compared with the GATT power-based mechanisms, the WTO dispute settlement system (DSS) is judicialized and rule-oriented. ${ }^{58}$ Introduction of the reverse consensus - which prevents a Member from blocking establishment of panels or the adoption of panel and $\mathrm{AB}$ reports, was an

\footnotetext{
${ }^{55}$ Thomas Cottier, A Theory of Direct Effect in Global Law, in EUROPEAN INTEGRATION AND INTERNATIONAL CO-ORDINATION: STUDIES IN TRANSNATIONAL ECONOMIC LAW IN HONOUR OF CLAUSDiETER EHLERMANN 60 (Claus-Dieter Ehlermann and others eds, Kluwer Law International 2002).

${ }^{56}$ See Weiler, supra n. 50, at 201.

${ }^{57}$ According to O'Donoghue, the rule of law, division of powers and democratic legitimacy are necessary components of a constitutionalized system. See Aoife O'DONOGHUE, CONSTITUTIONALISM in Global Constitutional Law 53 (Cambridge University Press 2014).

${ }^{58}$ See Matsushita, Schoenbaum \& Mavroidis, supra n. 25, at 108.
} 
important reform for the WTO DSS. ${ }^{59}$ Reverse consensus was designed to cure the abuses under the GATT DSS, and it was connected with the creation of the AB. One Canadian negotiator recalls that during the Uruguay Round negotiations the creation of the $\mathrm{AB}$ was proposed in order "to get the big guys, particularly the Americans and the Europeans, to sign onto this [the reverse consensus]. That's how people came up with the AB. It was to ensure adoption of panel reports". ${ }^{60}$ Thus the proposal to establish the AB was a bargaining chip to secure the support of big economies for reverse consensus, and not to create a constitutional court.

According to the DSU, the WTO DSS "serves to preserve the rights and obligations of the Members under the covered agreements, and to clarify the existing provisions of those agreements", ${ }^{61}$ and its primary function is to achieve a satisfactory settlement of the disputes between the Members. ${ }^{62}$ The establishment of panels depends on the requests made by the complaining Member. ${ }^{63}$ Nothing in the DSU suggests that WTO tribunals should function like a constitutional court to review the appeals from national courts or to take an initiative and review national law. In addition, WTO tribunals may suggest ways in which the losing party could implement WTO rulings, but these are only suggestions with no binding effect. ${ }^{64}$ Since the suggestions are not binding, the specific measures that are taken to implement WTO rulings are a matter of national law. Judicial implementation of WTO rulings is not required.

In US-Section 301 Trade Act, the Panel noted that specific obligations, creating rights for individuals, might follow from WTO rulings. However, it did not take a position on whether WTO rulings create direct effect for individuals. ${ }^{65}$ The panel took into account the clash that might occur between a Member's WTO obligations and internal constitutional principles,

\footnotetext{
${ }^{59}$ Craig Van Grasstek, The History and Future of the World Trade Organization 240. Available at https://www.wto.org/english/res_e/booksp_e/historywto_e.pdf (last visited Jan. 1, 2014).

${ }^{60}$ Ibid.

${ }^{61}$ See Art. 3.2 of the DSU.

${ }^{62}$ See Art. 3.4 of the DSU.

${ }^{63}$ See Art. 6 of the DSU.

${ }^{64}$ See Art. 19.1 of the DSU. The AB also stated that "Suggestions made by panels or the Appellate Body pursuant to Article 19.1 of the DSU regarding ways of implementation form part of panel or Appellate Body reports adopted by the DSB in previous proceedings. The DSU does not expressly address the question of the legal status of suggestions that form part of a report adopted by the DSB, nor does it specify the legal consequences when a Member chooses to implement DSB recommendations and rulings by following a suggestion for implementation. A Member may choose whether or not to follow a suggestion. The use of the term 'could' in Article 19.1 clarifies that Members are not obliged to follow suggestions for implementation". Article 21.5 Appellate Body Report, EC-Bananas III, WT/DS27/AR/RW/USA, para. 321.

${ }^{65}$ See Panel Report, US-Section 301 Trade Act, WT/DS152/R, footnote 661.
} 
thus concluded it was within national courts' domain to determine whether WTO obligations had direct effect.

Neither the WTO founders, nor the WTO adjudicators intended to attribute direct effect to WTO rulings. The text of the DSU itself is not particularly helpful on this point. The WTO tribunals are explicit in not taking a position on direct effect, and consider national courts more competent to determine this issue pursuant to their internal constitutional principles.

\section{B. Justification: From the Perspective of Institutional Structure}

The WTO institutional structure was not designed to resemble a constitutional framework. WTO law was neither framed with an intention of becoming a world trade constitution, nor does it provide a system of checks and balances among the WTO organs. ${ }^{66}$ The AB was not empowered to function as a constitutional court. Thus the legal effects of WTO rulings are not comparable with those of a national constitutional court. In fact, WTO tribunals have been criticized for judicial activism. ${ }^{67}$ Due to the lack of separation of powers within the WTO, and the lack of horizontal and vertical checks and balances within the WTO system, the denial of direct effect of WTO rulings is reasonable.

At the horizontal level, the WTO Ministerial Conference and the DSB do not have effective checks on WTO tribunals. ${ }^{68}$ Due to the reverse consensus, ${ }^{69}$ the DSB would find it very difficult, if not impossible, to reject or reverse panel's or the AB's findings and recommendations. As for the AB's interpretation of WTO law, it can be amended or reversed by the Ministerial Conference and the General Council by means of an amendment to or an authoritative interpretation of the covered agreements. ${ }^{70}$ In practice the WTO political organs' response to WTO rulings is muted due to the

\footnotetext{
${ }^{66}$ Jeffrey L Dunoff, Constitutional Conceits: The WTO's 'Constitution' and the Discipline of International Law, 17 EUR. J. INT’L L. 647, 657 (2006).

${ }^{67}$ See, for example, Richard H. Steinberg, Judicial Lawmaking at the WTO: Discursive, Constitutional, and Political Constraints, 98 AM. J. INT’L L. 247, 247 (2004).

${ }^{68}$ The WTO Ministerial Conference is at the apex of the WTO institutional structure. It is composed of representatives of all the Members and it meets at least once every two years. It has the power to decide all the matters under the Multilateral Trade Agreements. The General Council of the WTO, also composed of representatives of all the Members, is responsible for day-to-day management of the WTO and exercises the full power of the Ministerial Conference in the intervals between meetings of the Ministerial Council. The General Council also convenes as the Dispute Settlement Body (DSB), as well as the Trade Policy Review Body (TPRB). See Art. IV of the Marrakesh Agreement.

${ }^{69}$ See supra $\mathrm{n} .59$ and accompanying text.

${ }^{70}$ Article IX: 2 and X of the WTO Agreement.
} 
consensus rule of decision-making. ${ }^{71}$ Thus there are no effective political checks on WTO tribunals. Meanwhile, the actions of the WTO political organs are not subject to the review of WTO tribunals. There are no judicial checks on the WTO's political organs.

At the vertical level, a Member's legislative and executive measures are under the review of WTO tribunals, if those measures are challenged by other Members as inconsistent with WTO law. However, viewing begins only when a Member brings a case. There are no direct interactions between WTO tribunals and national courts. Unlike in the EU, there are no preliminary rulings in the WTO. The WTO tribunals' review of national measures is not qualified as vertical separation of powers between the WTO and the Member States. The review's exclusive purpose is dispute settlement and WTO rulings only bind the parties to the dispute. Although WTO tribunals have borrowed some constitutional doctrines such as the proportionality analysis, those doctrines are only narrowly applied in analysis of exceptional clauses set out in WTO law, and also dependent on the contingency of a Member's reference to exceptional clauses. ${ }^{72}$ Furthermore, the WTO lacks a demos and constituencies that form the foundation of a constitutional structure. ${ }^{73}$ Thus the WTO is not a constitutionalized entity.

Compared with national constitutional structures and the EU institutional framework, the WTO is a much less integrated entity that lacks horizontal and vertical separation of powers. Due to the lack of checks on WTO tribunals, it would be ill-advised to grant direct effect to WTO rulings.

\section{Justification: From the Perspective of Democratic Legitimacy}

The analysis of the WTO institutional structure shows that the WTO political organs do not constrain the WTO tribunals. Similarly, WTO Members' national parliaments exercise no control over them. Thus WTO tribunals are a dynamic engine which lacks effective control. Attributing direct effect to WTO rulings would be therefore risky.

From the substantive perspective, the WTO tribunals are authorized to settle the disputes among WTO Members. The tribunals often have to adjudicate on competing values and strike a balance between free trade objectives and non-trade concerns such as health, labor standards,

\footnotetext{
${ }^{71}$ Klaus Armingeon and others, The Constitutionalisation of International Trade Law, in THE Prospects of International TRAde Regulation: From Fragmentation to COHERENCE 83 (Thomas Cottier and Panagiotis Delimatsis eds, Cambridge University Press 2011).

${ }^{72}$ Ibid at $82-83$.

${ }^{73}$ See Joel P. Trachtman, The Constitutions of the WTO, 17 EUR. J. INT’L L. 623, 636 (2006).
} 
environment protection and human rights. ${ }^{74}$ However, since WTO tribunals are distanced from national constituencies and not answerable to national parliaments, ${ }^{75}$ WTO rulings may not reflect local preferences, and may lead to a democratic deficit. A case in point is EC-Biotech, ${ }^{76}$ which concerned the EC and its Members' regulatory control on genetically modified organisms (GMOs). The US complained that the control on GMOs restricted their exportation of agricultural and food products, which was against relevant provisions of WTO law. The complexities of the case posed serious challenges to the legitimacy of the panel's adjudication. According to Howse and Horn, the first challenge was "the limits of science, or technocratic regulatory controls, to protect against risk as perceived by real people". ${ }^{77}$ Although the EC control on GMOs was partly motivated by the public concerns about the safety of GMOs, it should be based on science and risk assessment, which tested the Panel's margin of deference and sensitivity as regards the risk assessment that was involved with divergent scientific views and the limits of the existing techniques. ${ }^{78}$ The second challenge was the WTO adjudicators' response to public feelings about food, which are related not only to physical health but also to spiritual concerns. ${ }^{79}$ The third challenge related to public distrust in multinational corporations. The food industry might have possessed more information about the risks of GMOs, however, the Panel was unable to summon industry witnesses or impose a duty of disclosure on any potential witnesses. ${ }^{80}$ The final challenge was the controversy relating to the policies towards GMOs. The dispute before the Panel was the one about GMOs between the EC and the US; however, a broader debate about the desirability, costs, and benefits of GMOs as a strategy for development and food security in developing countries was more striking. Thus the case tested the Panel's cooperation with broader international GMOs' regulation. ${ }^{81}$ It raises a fundamental question whether it was legitimate for WTO tribunals to adjudicate the

\footnotetext{
${ }^{74}$ Matthew Windsor, A Fine Balance? Delegation, Standards of Review, and Subsidiarity in WTO Dispute Settlement, 14 AucKLAND UnIVERSiTy LAW REVIEW 41, 53 (2008).

${ }^{75}$ See Trachtman, supra n. 74, 637.

${ }^{76}$ Panel Report, European Communities-Measures Affecting Approval and Marketing of Biotech Products, WT/DS291/R, WT/DS292/R, and WT/DS293/R (2006).

${ }^{77}$ Robert L. Howse and Henrik Horn, European Communities-Measures Affecting the Approval and Marketing of Biotech Products, 8 World TRAdE Review 49, 51 (2009).

${ }^{78}$ Ibid.

${ }^{79}$ German philosopher Feurbach used to state that "We are what we eat". People may link food with ethical, religious or spiritual misgivings. Ibid at $51-52$.

${ }^{80} \mathrm{Ibid}$ at 52 .

${ }^{81}$ Ibid at 53.
} 
dispute. $^{82}$

From the procedural perspective, the question arises whether the WTO tribunals are competent to decide on their own procedures. This is wellillustrated by the controversy relating to amicus curiae briefs, which position is not explicitly addressed by the DSU or by the Working Procedures for Appellate Review. In US-Shrimp, the first case raising this issue, the AB considered that the WTO tribunals had the authority to decide not to seek, accept or reject amicus curiae briefs. ${ }^{83}$ Some WTO Members protested, arguing that allowing non-governmental organizations (NGOs) and individuals to submit briefs would result in asymmetry, since WTO Members could partake in proceedings only if they acted as third parties in the dispute. ${ }^{84}$ In EC-Asbestos, pursuant to Rule 16(1) of the Working Procedures, the $\mathrm{AB}$ adopted an additional procedure to deal with amicus curiae submissions. It indicated that the additional procedure was "for the purposes of this appeal only" ${ }^{85}$ In reaction, some Members requested the General Council to convene a special meeting to discuss the matter ${ }^{86} \mathrm{~A}$ majority of the WTO Members considered it unacceptable for the AB to accept and consider amicus curiae briefs; However, the General Council did not make any decision. The $\mathrm{AB}$ did not follow the opinions of the majority of WTO Members. ${ }^{87}$ In EC-Sardines, the AB confirmed their authority to receive and consider amicus curiae briefs submitted by individuals and NGOs. Moreover, the AB also considered a brief from a Member who was not a third party in the case. ${ }^{88}$ This case shows that the General Council does not have significant control over WTO tribunals. The question arises whether it is legitimate for the $\mathrm{AB}$ to decide its procedures against the view of the large majority of WTO Members.

Whether substantively or procedurally, WTO tribunals have to deal with legal ambiguities and legal gaps. Since the chain of delegation to WTO tribunals on behalf of Member States principals is so long, WTO rulings may be against the will of the majority of WTO Members. Under these circumstances, appropriate political checks on WTO tribunals are advisable. However, due to the lack of institutional balance and the difficulty for WTO

\footnotetext{
${ }^{82}$ Ibid at 82.

${ }^{83}$ Appellate Body Report, US_-Shrimp, WT/DS58/AB/R, para. 104.

${ }^{84}$ Petros C. Mavroidis, Amicus Curiae Briefs before the WTO: Much Ado about Nothing (Jean Monnet Working Paper 2/01, 2001), at 4. Available at http://www.worldtradelaw.net/articles/mavroidisamicus.pdf.download (Last visited July 1, 2014).

${ }^{85}$ Appellate Body Report, EC-Asbestos, WT/DS135/AB/R, para. 51.

${ }^{86}$ The meeting took place on November 22, 2000.

${ }^{87}$ WTO doc. WT/GC/M/60, para. 31.

${ }^{88}$ Appellate Body Report, EC_-Sardines, WT/DS231/AB/R, paras.164, 167.
} 
political organs to make a decision, WTO tribunals' operation is not closely controlled by the Members. Furthermore, given that the Members do not have an intention to attribute direct effect to WTO rulings, it is not legitimate to require the Members to do so in their domestic legal orders.

\section{Proposal: Conditional DiREct EFFEct of WTO RULINGS}

The negative effects of and the reasons justifying the denial of direct effect of WTO rulings co-exist. For the sake of protecting individuals' interests promoting international rule of law, and fighting against negative effects, the WTO Members should consider attributing conditional direct effect to WTO rulings. Specifically, if a losing Member commits to comply with a WTO ruling and does not do so within the reasonable period of time, private parties should be allowed to rely on WTO rulings to initiate a complaint against the relevant national authorities in the national courts. However, if the defendants have good reasons to justify their noncompliance with WTO rulings, they should be immune or partly immune from the obligations to comply with WTO rulings in the national legal context. Whether the defendants are immune or partly immune from the obligations should depend on national courts' proportionality analysis in weighing and balancing different factors, such as the complainants' losses, causality between the losses and non-compliance with WTO rulings, public interests, allocation of the costs among economic actors, or the State's budget.

The scope of the proposed conditional direct effect is narrow. First, it is not argued that every Member should grant conditional direct effect to the WTO rulings in every case, but rather that conditional direct effect only applies to the parties to the dispute with respect to the ruling in that dispute. Second, it is not argued that a losing Member should fully compensate private parties' damages arising from the national authorities' noncompliance with a WTO ruling. Pursuant to proportionality analysis, national courts may order national authorities to make partial compensation, depending on the circumstances of each case. Third, national authorities' immunity from their obligation to comply with a WTO ruling in national legal context does not affect a Member's obligations in WTO legal context, which means that a Member is still bound by the WTO ruling in the international legal context.

This proposal is mainly based on two considerations: (1) The characteristics of WTO rulings qualify them to have direct effect, and (2) the positive effects deriving from conditional direct effect outweigh the 
negative effects. First, WTO rulings satisfy two objective criteria under which national courts can grant direct effect to international obligations: Clarity and completeness. ${ }^{89}$ In relation to "clarity", WTO rulings are the results of a dispute settlement process, and entail specific recommendations and rulings concerning the obligations that the parties should perform. What concerns "completeness", a losing Member has committed itself to comply with WTO rulings thus those WTO rulings, to a larger extent, are final and complete. Although the losing Member may try to find room for maneuver and continue to negotiate after the expiry of the reasonable period of time, endless negotiations should not be accepted as an appropriate means of implementation of WTO rulings. The difficulty is that the WTO rulings do not satisfy the subjective criterion of "intent", because WTO Members did not grant them direct effect.

Compared with WTO law, WTO rulings are more precise and pertinent, and directly bind the parties to the dispute. Most of the negative effects arising from direct effect of WTO law will not materialize in case of conditional direct effect of WTO rulings. According to Oliveira, the disadvantages of Brazilian courts' attributing direct effect to WTO law are as follows: "(1) A flood of individual cases, (2) diverse and inconsistent rulings among domestic courts within Brazil, (3) domestic courts' interpretation of WTO rules different from the international and foreign interpretation of trade rules, and finally (4) disequilibrium in international trade's concessions and rights." 90

The second and the third disadvantages would not apply to conditional direct effect. WTO rulings entail the interpretation of relevant provisions of WTO law, and they are clear and specific about the obligations that a losing Member should perform, thus no diverse, inconsistent, or deviated national rulings will occur. Regarding the first point, it is unlikely that WTO-related cases would pour national courts. Different from the general applicability of WTO law, WTO rulings are pertinent and address only specific legal issues, thus fewer private parties are affected by WTO rulings than those affected by WTO law. As for the fourth disadvantage, conditional direct effect benefits a Member's internal political and judicial checks and balances, and exhibits its respect for international rule of law. The prisoner's dilemma in

\footnotetext{
${ }^{89}$ As for the WTO rulings, "clarity" means whether WTO rulings are clear and precise about the obligations that a member should perform. "Completeness" means whether the content of WTO rulings is sufficiently complete to be given direct effect. See Nollkaemper, The Duality of Direct Effect of International Law, 25(1) EUR. J. INT'L L. 105, 115 (2014).

${ }_{90}$ Maria Angela Jardim de Santa Oliveira, International Trade Agreements Before Domestic Courts:

Lessons from the Brazilian Experience, at 22. Available at

http://papers.ssrn.com/sol3/papers.cfm?abstract_id=2448445 (Last visited Aug. 1, 2014).
} 
the implementation of WTO rulings should be solved and national courts are called upon to positively cooperate with the WTO tribunals.

Moreover, conditional direct effect will provide a judicial remedy for private parties, who are not direct participants of the WTO but whose interests are affected by a Member's non-compliance with WTO rulings. It will also provide an opportunity for national courts to check national authorities' non-compliance with WTO rulings and to fight against government failures. In addition, conditional direct effect will push national authorities to be more serious about their commitments to comply with WTO rulings, which has the potential of improving the international rule of law and also of enhancing security and predictability for economic operators.

At the same time, conditional direct effect will enhance the power of national courts. That may disturb original balance established between a Member's political and judicial organs, and may also open national courts to the criticisms by politicians. Yet, conditional direct effect is not automatic or unadaptable, because it allows national authorities to provide evidence to justify their non-compliance with WTO rulings. It also allows national courts to balance different values and interests involved in the implementation of WTO rulings. Note is taken that the WTO Members' interests may clash, and different Members may attach different importance to the same issue due to their various cultural and societal differences. At the same time, the conditional direct effect entails a safety valve that is activated by national courts' proportionality analysis. The inconsistency between WTO rulings and national rulings is likely to appear, when national courts conclude that non-compliance with WTO rulings is justified in national legal context. However, this outcome may be better than national courts' arbitrary denial of direct effect of WTO rulings, i.e., better than the US court's finding that WTO rulings were "not binding on the United States, much less this court". In fact, conditional direct effect is likely to improve the legitimacy of national rulings, because it requires national courts to listen to the parties, to deliberately and impartially make decisions in relation to WTO rulings. ${ }^{91}$

This proposal of conditional direct effect is based on Cottier's theory of multilayered governance, which provides that higher levels of law do not always prevail. "A2 "As all layers of governance are prone to failure, checks and balances need to cut both ways." ${ }^{93}$ Conditional direct effect of WTO

\footnotetext{
${ }^{91}$ See Weiler, supra n. 50.

${ }^{92}$ Thomas Cottier, International Trade Law: The Impact of Justiciability and Separations of Powers in EC Law, 5 EUROPEAN CONSTITUTIONAL LAW REVIEW 307, 323 (2009).

${ }^{93}$ Ibid.
} 
rulings would provide a chance for national courts to check national authorities' non-compliance with WTO rulings and WTO law. The function of double checks entailed in conditional direct effect does not only demonstrates national courts' respect for WTO rulings, ${ }^{94}$ but also takes into account a Member's sovereignty. In addition, conditional direct effect reflects the philosophy of tolerance. Tolerance is an essential component for a democratic and civilized society, ${ }^{95}$ which corresponds to the theory of multilayered governance. Conditional direct effect entails national courts' tolerance of WTO rulings' piercing effect on national legal order, and it also entails WTO tribunals' tolerance of national authorities' justification of noncompliance with WTO rulings in the national legal context. The boundary of those two categories of tolerance is that the national authorities' justification of non-compliance with WTO rulings only applies at national level and will not affect a Member's WTO obligations at international level. The essence of conditional direct effect is to mildly intensify the piercing effect of WTO rulings so as to strengthen the cooperation between WTO governance and national governance.

\section{CONCLUSION}

The obligation to honour WTO rulings is imbedded in the parties' primary obligation to comply with WTO law. It seems WTO rulings are no more binding than WTO law, and then the members need not be bothered to grant direct effect to WTO rulings, given the fact that WTO law per se lacks direct effect. The EU and the US courts are indeed reluctant to recognize direct effect of WTO rulings. Nevertheless, a close examination of the EU and the US jurisprudence reveals that negative effects of and the reasons justifying the denial of direct effect of WTO rulings co-exist. In fact, as for the parties to a dispute, WTO rulings are no less binding than WTO law, because the rulings are more precise and pertinent. Therefore, a more balanced approach is to attribute conditional direct effect to WTO rulings. Such an approach corresponds to Cottier's theory of multi-layered governance, gives diligent consideration to the protection of individuals' interests, and promotes international rule of law.

\footnotetext{
${ }^{94}$ In no way does national courts' arbitrary denial of direct effect of WTO rulings express their respect for WTO rulings. In-depth and deliberate analysis of WTO rulings indeed shows a serious attitude towards and respect for WTO rulings.

${ }^{95}$ Here "tolerance" stresses the meaning of "a fair, objective, and permissive attitude toward those whose opinions, practices, race, religion, nationality, etc., differ from one's own; freedom from bigotry." Richard Pimentel, The Philosophy of Tolerance,

http://www.philosophynews.com/page/The-Philosophy-of-Tolerance.aspx (last visited July 29, 2014).
} 